\title{
Feasibility analysis of using inverse modeling for estimating field-scale evapotranspiration in maize and soybean fields from soil water content monitoring networks
}

\author{
Foad Foolad ${ }^{1}$, Trenton E. Franz ${ }^{2}$, Tiejun Wang ${ }^{2,3}$, Justin Gibson ${ }^{2}$, Ayse Kilic ${ }^{1,2}$, Richard G. Allen ${ }^{4}$, and \\ Andrew Suyker ${ }^{2}$ \\ ${ }^{1}$ Civil Engineering Department, University of Nebraska, Lincoln, NE, USA \\ ${ }^{2}$ School of Natural Resources, University of Nebraska, Lincoln, NE, USA \\ ${ }^{3}$ Institute of Surface-Earth System Science, Tianjin University, Tianjin, People's Republic of China \\ ${ }^{4}$ Kimberly Research and Extension Center, University of Idaho, Kimberly, ID, USA \\ Correspondence to: Trenton E. Franz (tfranz70@gmail.com)
}

Received: 23 August 2016 - Discussion started: 26 August 2016

Revised: 9 February 2017 - Accepted: 14 February 2017 - Published: 2 March 2017

\begin{abstract}
In this study, the feasibility of using inverse vadose zone modeling for estimating field-scale actual evapotranspiration $\left(\mathrm{ET}_{\mathrm{a}}\right)$ was explored at a long-term agricultural monitoring site in eastern Nebraska. Data from both point-scale soil water content (SWC) sensors and the areaaverage technique of cosmic-ray neutron probes were evaluated against independent $\mathrm{ET}_{\mathrm{a}}$ estimates from a co-located eddy covariance tower. While this methodology has been successfully used for estimates of groundwater recharge, it was essential to assess the performance of other components of the water balance such as $\mathrm{ET}_{\mathrm{a}}$. In light of recent evaluations of land surface models (LSMs), independent estimates of hydrologic state variables and fluxes are critically needed benchmarks. The results here indicate reasonable estimates of daily and annual $\mathrm{ET}_{\mathrm{a}}$ from the point sensors, but with highly varied soil hydraulic function parameterizations due to local soil texture variability. The results of multiple soil hydraulic parameterizations leading to equally good $\mathrm{ET}_{\mathrm{a}}$ estimates is consistent with the hydrological principle of equifinality. While this study focused on one particular site, the framework can be easily applied to other SWC monitoring networks across the globe. The value-added products of groundwater recharge and $\mathrm{ET}_{\mathrm{a}}$ flux from the SWC monitoring networks will provide additional and more robust benchmarks for the validation of LSM that continues to improve their forecast skill. In addition, the value-added products of groundwater recharge and $\mathrm{ET}_{\mathrm{a}}$ often have more direct im-
\end{abstract}

pacts on societal decision-making than SWC alone. Water flux impacts human decision-making from policies on the long-term management of groundwater resources (recharge), to yield forecasts $\left(\mathrm{ET}_{\mathrm{a}}\right)$, and to optimal irrigation scheduling $\left(\mathrm{ET}_{\mathrm{a}}\right)$. Illustrating the societal benefits of SWC monitoring is critical to insure the continued operation and expansion of these public datasets.

\section{Introduction}

Evapotranspiration (ET) is an important component in terrestrial water and surface energy balance. In the United States, ET comprises about $75 \%$ of annual precipitation, while in arid and semiarid regions, ET comprises more than $90 \%$ of annual precipitation (Zhang et al., 2001; Glenn et al., 2007; Wang et al., 2009a). As such, an accurate estimation of ET is critical in order to predict changes in hydrological cycles and improve water resource management (Suyker and Verma, 2008; Anayah and Kaluarachchi, 2014). Given the importance of ET, an array of measurement techniques at different temporal and spatial scales have been developed (see Maidment, 1992; Zhang et al., 2014), including lysimeter, Bowen ratio, eddy covariance (EC), and satellite-based surface energy balance approaches. However, simple, low-cost, and accurate field-scale measurements of actual ET $\left(\mathrm{ET}_{\mathrm{a}}\right)$ still remain a challenge due to the uncertainties of available estima- 
tion techniques (Wolf et al., 2008; Li et al., 2009; Senay et al., 2011; Stoy, 2012). For instance, field techniques, such as EC and Bowen ratio, can provide relatively accurate estimation of local $\mathrm{ET}_{\mathrm{a}}$, but are often cost prohibitive for widespread use beyond research applications (Baldocchi et al., 2001; Irmak, 2010). By comparison, satellite-based remote sensing techniques are far less costly for widespread spatial coverage (Allen et al., 2007), but are limited by their accuracy, temporal sampling frequency (e.g., Landsat 8 has a 16-day overpass), and technical issues that further limit temporal sampling periods (e.g., cloud coverage during overpass) (Chemin and Alexandridis, 2001; Xie et al., 2008; Li et al., 2009; Kjaersgaard et al., 2012).

As a complement to the above-mentioned techniques, recent studies have used process-based vadose zone models (VZMs) for estimating field-scale $\mathrm{ET}_{\mathrm{a}}$ with reasonable success, particularly in arid and semiarid areas (Twarakavi et al., 2008; Izadifar and Elshorbagy, 2010; Galleguillos et al., 2011; Wang et al., 2016). Although VZMs are time and cost effective for estimating field-scale $\mathrm{ET}_{\mathrm{a}}$, they generally require complex model parameterizations and inputs, some of which are not readily available (e.g., soil hydraulic parameters and plant physiological parameters; see Wang et al., 2016). In order to address the issue of missing soil hydraulic parameters, a common approach is to use pedotransfer functions to convert readily available soil information (texture, bulk density, etc.) to soil hydraulic parameters (Wösten et al., 2001); however, significant uncertainties are usually associated with this method for estimating local-scale water fluxes (Wang et al., 2015). In fact, Nearing et al. (2016) identified soil hydraulic property estimation as the largest source of information lost when evaluating different land surface modeling schemes versus a soil moisture benchmark. Poor and uncertain parameterization of soil hydraulic properties is a clear weakness of land surface model (LSM) predictive skill in sensible and latent heat fluxes (Best et al., 2015). This problem will continue to compound with the continuing spatial refinement of hyper-resolution LSM grid cells to less than $1 \mathrm{~km}$ (Wood et al., 2011).

In order to address the challenge of field-scale estimation of soil hydraulic properties, here we utilize inverse modeling for estimating soil hydraulic parameters based on field measurements of soil water content (SWC) (see Hopmans and Šimunek, 1999; Ritter et al., 2003). While VZM-based inverse approaches have already been examined for estimating groundwater recharge (e.g., Jiménez-Martínez et al., 2009; Andreasen et al., 2013; Min et al., 2015; Ries et al., 2015; Turkeltaub et al., 2015; Wang et al., 2016), their application for $\mathrm{ET}_{\mathrm{a}}$ estimation has not been adequately tested. Moreover, we note that simultaneous estimation of SWC states and surface energy fluxes within LSMs is complicated by boundary conditions, model parameterization, and model structure (Nearing et al., 2016). With the incorporation of regional soil datasets in LSMs like Polaris (Chaney et al., 2016), effective strategies for estimating ground truth soil hydraulic proper- ties from existing SWC monitoring networks (e.g., SCAN, CRN, COSMOS, State/National Mesonets; see Xia et al., 2015) will become critical for continuing to improve the predictive skill of LSMs.

The aim of this study is to examine the feasibility of using inverse VZMs for estimating field-scale $\mathrm{ET}_{\mathrm{a}}$ based on long-term local meteorological and SWC observations for an AmeriFlux (Baldocchi et al., 2001) EC site in eastern Nebraska, USA. We note that while this study focused on one particular study site in eastern Nebraska, the methodology can be easily adapted to a variety of SWC monitoring networks across the globe (Xia et al., 2015), thus providing an extensive set of benchmark data for use in LSMs. The remainder of the paper is organized as follows. In the methods section, we will describe the widely used VZM, Hydrus-1D (Šimunek et al., 2013), used to obtain soil hydraulic parameters. We will assess the feasibility of using both profiles of in situ SWC probes as well as the area-average SWC technique from cosmic-ray neutron probes (CRNPs). In the results section, we will compare simulated $\mathrm{ET}_{\mathrm{a}}$ resulted from calibrated VZM with independent $\mathrm{ET}_{\mathrm{a}}$ estimates provided by $\mathrm{EC}$ observations. Finally, a sensitivity analysis of key soil and plant parameters will be presented.

\section{Materials and methodology}

\subsection{Study site}

The study site is located in eastern Nebraska, USA, at the University of Nebraska Agricultural and Development Center near Mead. The field site (US-Ne3, $41.1797^{\circ} \mathrm{N}$, $96.4397^{\circ} \mathrm{W}$; Fig. 1a) is part of the AmeriFlux Network (Baldocchi et al., 2001) and has been operating continually since 2001. The regional climate is of a continental semiarid type with a mean annual precipitation of $784 \mathrm{~mm} \mathrm{yr}^{-1}$ (according to the AmeriFlux US-Ne3 website). According to the Web Soil Survey data (Soil Survey Staff, 2016, http: //websoilsurvey.nrcs.usda.gov/), the soils at the site are comprised mostly of silt loam and silty clay loam (Fig. 1b and Table 1). Soybean and maize are rotationally grown at the site under rain-fed conditions, with the growing season beginning in early May and ending in October (Kalfas et al., 2011). Since 2001, crop management practices (i.e., planting density, cultivars, irrigation, and herbicide and pesticide applications) have been applied in accordance with standard best management practices prescribed for production-scale maize systems (Suyker and Verma, 2008). More detailed information about site conditions can be found in Suyker et al. (2004) and Verma et al. (2005).

An EC tower was constructed at the center of the field (Figs. 1 and 2a) and continuously measures water, energy, and $\mathrm{CO}_{2}$ fluxes (e.g., Baldocchi et al., 1988). At this field, sensors are mounted at $3.0 \mathrm{~m}$ above the ground when the canopy is shorter than $1.0 \mathrm{~m}$. At canopy heights greater than 
Table 1. Variability of soil texture in the study field based on Web Soil Survey data (http://websoilsurvey.sc.egov.usda.gov/App/HomePage. htm).

\begin{tabular}{llrrrrr}
\hline $\begin{array}{l}\text { Map unit } \\
\text { symbol }\end{array}$ & Map unit name & $\begin{array}{r}\text { Clay } \\
(\%)\end{array}$ & $\begin{array}{r}\text { Silt } \\
(\%)\end{array}$ & $\begin{array}{r}\text { Sand } \\
(\%)\end{array}$ & $\begin{array}{r}\text { Hectares in } \\
\text { field }\end{array}$ & $\begin{array}{r}\text { Percent of } \\
\text { field }\end{array}$ \\
\hline 3948 & Fillmore silt loam, terrace, occasionally ponded & 41.7 & 51.0 & 7.3 & 3.24 & $4.9 \%$ \\
7105 & Yutan silty clay loam, terrace, 2 to 6\% slopes, eroded & 25.8 & 59.4 & 14.8 & 6.88 & $10.3 \%$ \\
7280 & Tomek silt loam, 0 to 2\% slopes & 32.3 & 61.6 & 6.1 & 47.23 & $70.8 \%$ \\
7340 & Filbert silt loam, 0 to 1\% slopes & 41.4 & 51.7 & 6.9 & 9.34 & $14.0 \%$ \\
\hline & Total area of field & & & & 66.69 & $100.0 \%$ \\
\hline
\end{tabular}

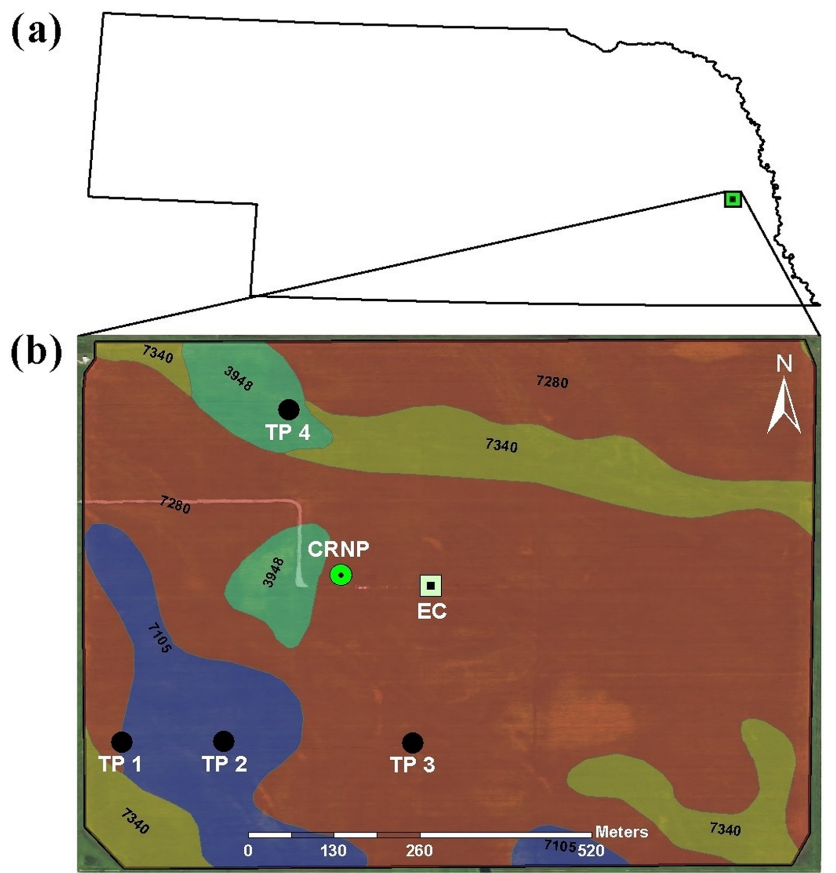

Figure 1. Study site (Mead rain-fed/US-Ne3) location in Nebraska (a) and locations of the eddy covariance tower (EC), cosmicray neutron probe (CRNP), ThetaProbes (TPs), and variability of soil texture based on Web Soil Survey data at the study site, 2014 (b). See Table 1 for soil descriptions.

$1.0 \mathrm{~m}$, the sensors are then moved to a height of $6.2 \mathrm{~m}$ until harvest in order to have sufficient upwind fetch (in all directions) representative of the cropping system being studied (Suyker et al., 2004). In this study, hourly latent heat flux measurements were integrated to daily values and then used for calculating daily EC ET $\mathrm{a}$ integrated over the field scale. Detailed information on the EC measurements and calculation procedures for $\mathrm{ET}_{\mathrm{a}}$ are given in Suyker and Verma (2009). Hourly air temperature, relative humidity, horizontal wind speed, net radiation, and precipitation were also measured at the site. Destructive measurements of leaf area index (LAI) were made every 10 to 14 days during the growing season at the study site (Suyker et al., 2005). We note that the LAI data were linearly interpolated to provide daily
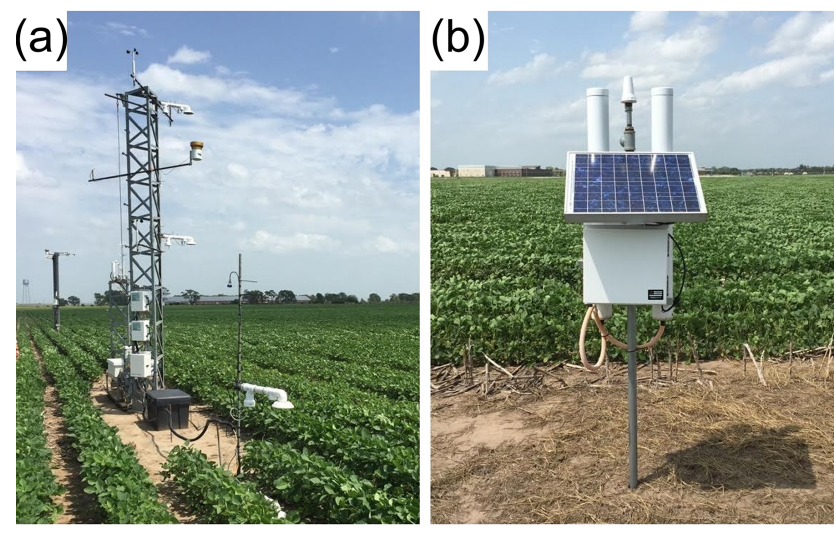

Figure 2. Eddy covariance tower (a) and cosmic-ray neutron probe (b) located at the Mead rain-fed (US-Ne3) site.

estimates. ThetaProbes (TPs) (Delta-T Devices, Cambridge, UK) were installed at four locations in the study field with measurement depths of $10,25,50$, and $100 \mathrm{~cm}$ at each location to monitor hourly SWC in the root zone (Suyker and Verma, 2008). Here, we denote these four locations as TP 1 $\left(41.1775^{\circ} \mathrm{N}, 96.4442^{\circ} \mathrm{W}\right)$, TP $2\left(41.1775^{\circ} \mathrm{N}, 96.4428^{\circ} \mathrm{W}\right)$, TP $3\left(41.1775^{\circ} \mathrm{N}, 96.4402^{\circ} \mathrm{W}\right)$, and TP $4\left(41.1821^{\circ} \mathrm{N}\right.$, $\left.96.4419^{\circ} \mathrm{W}\right)$ (Fig. 1b). Daily precipitation $(P)$ and reference evapotranspiration $\left(\mathrm{ET}_{\mathrm{r}}\right)$, computed for the tall (alfalfa) reference crop using the ASCE standardized Penman-Monteith equation (ASCE-EWRI, 2005), are shown in Fig. 3 for the study period (2007-2012) at the study site.

In addition, a CRNP (model CRS 2000/B, HydroInnova LLC, Albuquerque, NM, USA; $41.1798^{\circ} \mathrm{N}, 96.4412^{\circ} \mathrm{W}$ ) was installed near the EC tower (Figs. $1 \mathrm{~b}$ and $2 \mathrm{~b}$ ) on 20 April 2011. The CRNP measures hourly moderated neutron counts (Zreda et al., 2008, 2012), which are converted into SWC following standard correction procedures and calibration methods (see Zreda et al., 2012). In addition, the changes in aboveground biomass were removed from the CRNP estimates of SWC following Franz et al. (2015). The CRNP measurement depth (Franz et al., 2012) at the site varies between 15 and $40 \mathrm{~cm}$, depending on SWC. Note that, for simplicity in this analysis, we assume the CRNP has an effective depth of $20 \mathrm{~cm}$ (mean depth of $10 \mathrm{~cm}$ ) for all observational peri- 


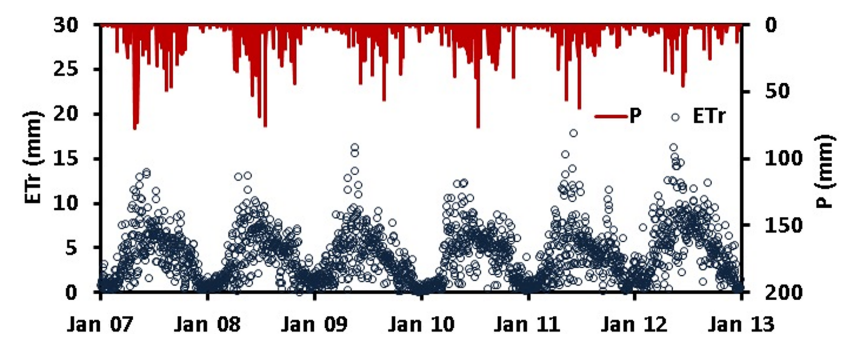

Figure 3. Daily precipitation $(P)$ and reference evapotranspiration $\left(\mathrm{ET}_{\mathrm{r}}\right)$ during the calibration (2008-2010) and validation (20112012) periods at the Mead rain-fed (US-Ne3) site.

ods. The areal footprint of the CRNP is $\sim 250 \pm 50 \mathrm{~m}$ radius circle (see Desilets and Zreda, 2013 and Köhli et al., 2015 for details). Here, we assume for simplicity that the EC and CRNP footprints are both representative of the areal-average field conditions.

\subsection{Model setup}

\subsubsection{Vadose zone model}

The Hydrus-1D model (Šimunek et al., 2013), which is based on the Richards equation, was used to calculate $\mathrm{ET}_{\mathrm{a}}$. The setup of the Hydrus-1D model is explained in detail by Jiménez-Martínez et al. (2009), Min et al. (2015), and Wang et al. (2016), and only a brief description of the model setup is provided here. Given the measurement depths of the ThetaProbes, the simulated soil profile length was chosen to be $175 \mathrm{~cm}$ with 176 nodes at $1 \mathrm{~cm}$ intervals. An atmospheric boundary condition with surface runoff was selected as the upper boundary. This allowed the occurrence of surface runoff when precipitation rates were higher than soil infiltration capacity or if the soil became saturated. According to a nearby USGS monitoring well (Saunders County, NE, USGS 411005096281502, $2.7 \mathrm{~km}$ away), the depth to water tables was greater than $12 \mathrm{~m}$ during the study period. Therefore, free drainage was used as the lower boundary condition.

Based on the ASCE Penman-Monteith equation, $\mathrm{ET}_{\mathrm{r}}$ values can be computed for either grass or alfalfa and then, using crop-specific coefficients, daily potential evapotranspiration $\left(\mathrm{ET}_{\mathrm{p}}\right)$ can be calculated. Here, daily $\mathrm{ET}_{\mathrm{r}}$ values were calculated for the tall $(0.5 \mathrm{~m})$ ASCE reference (ASCE-EWRI, $2005)$, and daily potential evapotranspiration $\left(E_{\mathrm{p}}\right)$ was calculated according to FAO 56 (Allen et al., 1998):

$\operatorname{ET}_{\mathrm{p}}(t)=K_{\mathrm{c}}(t) \times \mathrm{ET}_{\mathrm{r}}(t)$,

where $K_{\mathrm{c}}$ is a crop-specific coefficient at time $t$. The estimates of growth stage lengths and $K_{\mathrm{c}}$ values for maize and soybean suggested by Allen et al. (1998) and Min et al. (2015) were adopted in this study. In order to partition daily $\mathrm{ET}_{\mathrm{p}}$ into potential transpiration $\left(T_{\mathrm{p}}\right)$ and potential evaporation $\left(E_{\mathrm{p}}\right)$ as model inputs, Beer's law (Šimunek et al.,
2013) was used as follows:

$E_{\mathrm{p}}(t)=\mathrm{ET}_{\mathrm{p}}(t) \times e^{-k \times \mathrm{LAI}(t)}$

$T_{\mathrm{p}}(t)=\mathrm{ET}_{\mathrm{p}}(t)-E_{\mathrm{p}}(t)$,

where $k[-]$ is an extinction coefficient with a value set to 0.5 (Wang et al., 2009b) and LAI $\left[\mathrm{L}^{2} \mathrm{~L}^{-2}\right]$ is leaf area index described in the previous section. The root water uptake, $S(h)$, was simulated according to the model of Feddes et al. (1978):

$S(h)=\alpha(h) \times S_{\mathrm{p}}$,

where $\alpha(h)[-]$ is the root water uptake water stress response function and varies between 0 and 1 depending on soil matric potentials, and $S_{\mathrm{p}}$ is the potential water uptake rate and assumed to be equal to $T_{\mathrm{p}}$. The summation of actual soil evaporation and actual transpiration is $\mathrm{ET}_{\mathrm{a}}$.

Since the study site has annual cultivation rotations between soybean and maize, the root growth model from the Hybrid-Maize model (Yang et al., 2004) was used to model the root growth during the growing season:

$\left\{\begin{aligned} \text { if } D<\mathrm{MRD}, D & =\frac{\mathrm{AGDD}}{\mathrm{GDD}_{\text {Silking }}} \mathrm{MRD} \\ \text { or } D & =\mathrm{MRD}^{\text {MRD }}\end{aligned}\right.$,

where $D(\mathrm{~cm})$ is plant root depth for each growing season day, MRD is the maximum root depth (assumed equal to $150 \mathrm{~cm}$ for maize and $120 \mathrm{~cm}$ for soybean in this study following Yang et al., 2004), AGDD is the accumulated growing

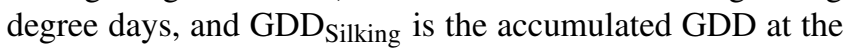
silking point (e.g., accumulated plant GDD approximately 60-70 days after crop emergence). GDD for each growing season day was calculated as

$\mathrm{GDD}=\frac{T_{\max }-T_{\min }}{2}-T_{\text {base }}$,

where $T_{\max }$ and $T_{\min }$ are the maximum and minimum daily temperature $\left({ }^{\circ} \mathrm{C}\right)$, respectively, and $T_{\text {base }}$ is the base temperature set to be $10^{\circ} \mathrm{C}$ following McMaster and Wilhelm (1997) and Yang et al. (1997). Finally, the Hoffman and van Genuchten (1983) model was used to calculate root distribution. Further details about the model can be found in Šimunek et al. (2013).

\subsubsection{Inverse modeling to estimate soil hydraulic parameters}

Inverse modeling was used to estimate soil hydraulic parameters for the van Genuchten-Mualem model (Mualem, 1976; van Genuchten, 1980):

$\theta(h)=\left\{\begin{array}{l}\theta_{\mathrm{r}}+\frac{\theta_{\mathrm{s}}-\theta_{\mathrm{r}}}{\left(1+|\alpha h|^{n}\right)^{m}}, h<0 \\ \theta_{\mathrm{s}}, h \geq 0\end{array}\right.$
$K\left(S_{e}\right)=K_{\mathrm{s}} \times S_{e}^{l} \times\left[1-\left(1-S_{e}^{1 / m}\right)^{m}\right]^{2}$,

where $\theta\left[\mathrm{L}^{3} \mathrm{~L}^{-3}\right]$ is volumetric SWC; $\theta_{\mathrm{r}}\left[\mathrm{L}^{3} \mathrm{~L}^{-3}\right]$ and $\theta_{\mathrm{S}}$ $\left[\mathrm{L}^{3} \mathrm{~L}^{-3}\right]$ are residual and saturated water content, respec- 
tively; $h[\mathrm{~L}]$ is pressure head; $K\left[\mathrm{~L} \mathrm{~T}^{-1}\right]$ and $K_{\mathrm{S}}\left[\mathrm{L} \mathrm{T}^{-1}\right]$ are unsaturated and saturated hydraulic conductivity, respectively; and $S_{e}\left(=\left(\theta-\theta_{\mathrm{r}}\right) /\left(\theta_{\mathrm{s}}-\theta_{\mathrm{r}}\right)\right)[-]$ is saturation degree. With respect to the fitting factors, $\alpha\left[1 \mathrm{~L}^{-1}\right]$ is inversely related to air entry pressure, $n[-]$ measures the pore size distribution of a soil with $m=1-1 / n$, and $l[-]$ is a parameter accounting for pore space tortuosity and connectivity.

Daily SWC data from the four TP locations and CRNP location were used for the inverse modeling. Based on the measurement depths of the TPs, the simulated soil columns were divided into four layers for TP locations (i.e., 0-15, 15-35, $35-75$, and $75-175 \mathrm{~cm}$ ), which led to a total of 24 hydraulic parameters $\left(\theta_{\mathrm{r}} ; \theta_{\mathrm{s}} ; \alpha, n, K_{\mathrm{s}}\right.$, and $\left.l\right)$ to be optimized based on observed SWC values. In order to efficiently optimize the parameters, we used the method outlined in Turkeltaub et al. (2015). Since Hydrus-1D is limited to optimizing a maximum of 15 parameters at once and that the SWC of the lower layers changes more slowly and over a smaller range than the upper layers, the van Genuchten parameters of the upper two layers were first optimized, while the parameters of the lower two layers were fixed. Then, the optimized van Genuchten parameters of the upper two layers were kept constant, while the parameters of the lower two layers were optimized. The process was continued until there were no further improvements in the optimized hydraulic parameters or until the changes in the lowest sum of squares were less than $0.1 \%$. Given the sensitivity of the optimization results to the initial guesses of soil hydraulic parameters in the Hydrus model, soil hydraulic parameters from six soil textures were used as initial inputs for the optimizations at each location (Carsel and Parish, 1988), including sandy clay loam, silty clay loam, loam, silt loam, silt, and clay loam. Based on the length of available SWC data from the TP measurements, the periods of 2007, 2008-2010, and 2011-2012 were used as the spin-up, calibration, and validation periods, respectively. Moreover, to minimize the impacts of freezing conditions on the quality of SWC measurements, data from January to March of each calendar year were removed (based on available soil temperature data) from the optimizations.

In addition to the TP profile observations, we used the CRNP area-average SWC in the inverse procedure to develop an independent set of soil parameters. The CRNP was assumed to provide SWC data with an average effective measurement depth of $20 \mathrm{~cm}$ at this study site. The observation point was therefore set at $10 \mathrm{~cm}$. As a first guess and in the absence of other information, soil properties were assumed to be homogeneous throughout the simulated soil column with a length of $175 \mathrm{~cm}$. Because the CRNP was installed in 2011 at the study site, the periods of 2011, 2012-2013, and 2014 were used as spin-up, calibration, and validation periods, respectively, for the optimization procedure.

The lower and upper bounds of each van Genuchten parameter are provided in Table 2. With respect to the goodness-of-fit assessment, root mean square error (RMSE) between simulated and observed SWC was chosen as the objective function to minimize in order to estimate the soil hydraulic parameters. The built-in optimization procedure in Hydrus-1D was used to perform parameter estimation. A sensitivity analysis of the six soil model parameters was performed. In addition, three additional performance criteria, including coefficient of determination $\left(R^{2}\right)$, mean average error (MAE), and the Nash-Sutcliffe Efficiency (NSE) were used to further evaluate and validate the selected model behavior:

$$
\begin{aligned}
& \text { RMSE }=\sqrt{\frac{1}{n} \sum_{i=1}^{n}\left(P_{i}-O_{i}\right)^{2}} \\
& R^{2}=\left(\frac{n\left(\sum_{i=1}^{n} P_{i} O_{i}\right)-\left(\sum_{i=1}^{n} P_{i}\right)\left(\sum_{i=1}^{n} O_{i}\right)}{\sqrt{\left[n \sum_{i=1}^{n} P_{i}^{2}-\left(\sum_{i=1}^{n} P_{i}\right)^{2}\right]\left[n \sum_{i=1}^{n} O_{i}^{2}-\left(\sum_{i=1}^{n} O_{i}\right)^{2}\right]}}\right)^{2} \\
& \mathrm{MAE}=\frac{1}{n} \sum_{i=1}^{n}\left|P_{i}-O_{i}\right| \\
& \mathrm{NSE}=1-\frac{\sum_{i=1}^{n}\left(P_{i}-O_{i}\right)^{2}}{\sum_{i=1}^{n}\left(O_{i}-\bar{O}_{i}\right)^{2}}
\end{aligned}
$$

where $n$ is the total number of SWC data points; $O_{i}$ and $P_{i}$ are, respectively, the observed and simulated daily SWC on day $i$; and $\bar{O}_{i}$ is the observed mean value. Based on the best scores (i.e., lowest RMSE values), the best optimized set of soil hydraulic parameters at each location was selected. Using the selected parameters, the Hydrus model was then run in a forward mode in order to estimate $\mathrm{ET}_{\mathrm{a}}$ between 2007 and 2012. Finally, we note that the years 2004-2006 were used as a model spin-up period for the forward model and evaluation of $\mathrm{ET}_{\mathrm{a}}$ because of the longer climate record length.

\section{Results and discussions}

\subsection{Vadose zone inverse modeling results}

The time series of the average SWC from the four TP locations along with 1 standard deviation at each depth are plotted in Fig. 4. Based on the large spatial standard deviation values (Fig. 4), despite the relatively small spatial scale ( $\sim 65$ ha) and uniform cropping at the study site, SWC varies considerably across the site, particularly during the growing season. The comparison between SWC data from the CRNP and spatial average of SWC data at the four TP locations in the study field (i.e., average of 10 and $25 \mathrm{~cm}$ depths at TP locations) is presented in Fig. 5. The daily RMSE between the spatial average of the TPs and CRNP data is $0.037 \mathrm{~cm}^{3} \mathrm{~cm}^{-3}$, which is consistent with other studies that reported similar values in semiarid shrublands (Franz et al., 2012), German forests (Bogena et al., 2013; Baatz et al., 2014), montane forests in Utah (Lv et al., 2014), sites across Australia (Hawdon et al., 2014), and a mixed land use agricultural site in Austria (Franz et al., 2016). We note that we would expect lower RMSE $\left(\sim<0.02 \mathrm{~cm}^{3} \mathrm{~cm}^{-3}\right)$ with additional point sensors located at shallower depths and in more locations distributed across the study site. Nevertheless, the consistent be- 
Table 2. Bounds of the van Genuchten parameters used for inverse modeling.

\begin{tabular}{lrrrrrr}
\hline Soil parameter & $\theta_{\mathrm{r}}(-)$ & $\theta_{s}(-)$ & $\alpha\left(1 \mathrm{~cm}^{-1}\right)$ & $n(-)$ & $K_{\mathrm{S}}\left(\mathrm{cm} \mathrm{day}^{-1}\right)$ & $l(-)$ \\
\hline Range & $0.03-0.30$ & $0.3-0.6$ & $0.001-0.200$ & $1.01-6.00$ & $1-200$ & $-1-1$ \\
\hline
\end{tabular}
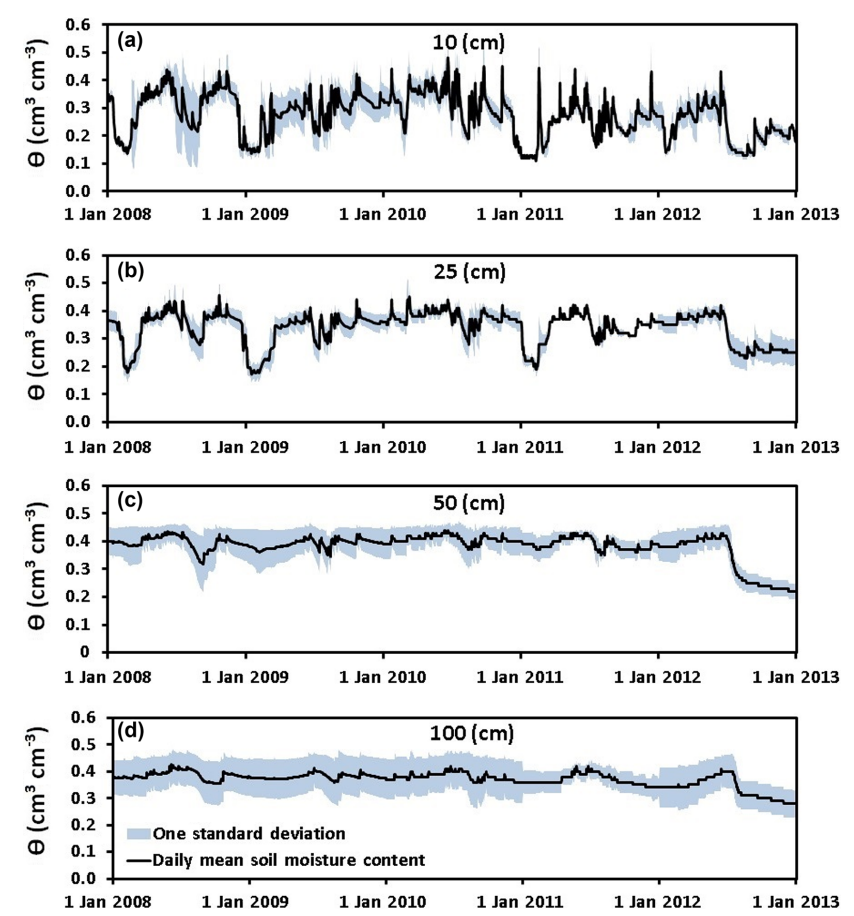

Figure 4. Temporal evolution of daily $\operatorname{SWC}(\theta)$ at different soil depths. The black lines represent daily mean SWC $(\theta)$ calculated from TPs in four different locations at the study site and the blue areas indicate 1 standard deviation.

havior between the spatial mean SWC of TPs and the CRNP allows us to explore spatial variability of soil hydraulic properties within the footprint using inverse modeling. This will be described in the next sections. The study period (20072012; Fig. 6) contained significant interannual variability in precipitation. During the spin-up period in 2007, the annual precipitation $(942 \mathrm{~mm}$ ) was higher than the mean annual precipitation (784 mm); 2008 was a wet year $(997 \mathrm{~mm}) ; 2009$ 2011 were near-average years $(715 \mathrm{~mm})$; and 2012 was a record dry year $(427 \mathrm{~mm})$ with widespread drought across the region. Therefore, both wet and dry years were considered in the inverse modeling simulation period.

As an illustration, Fig. 7 shows the daily observed and simulated SWC during the calibration (2008-2010) and validation (2011-2012) periods at the TP 1 location (the simulation results of the other three sites can be found in the Supplement Figs. S1, S2, and S3). The results of objective function criterion (RMSE) and the other three performance criteria (e.g., $R^{2}$, MAE, and NSE) between simulated and observed SWC values at TP locations are presented in Table 3.

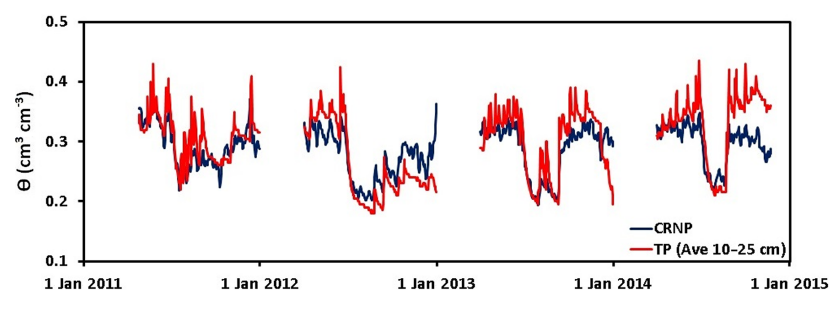

Figure 5. Time series of daily CRNP and spatial average TP SWC $(\theta)$ data.

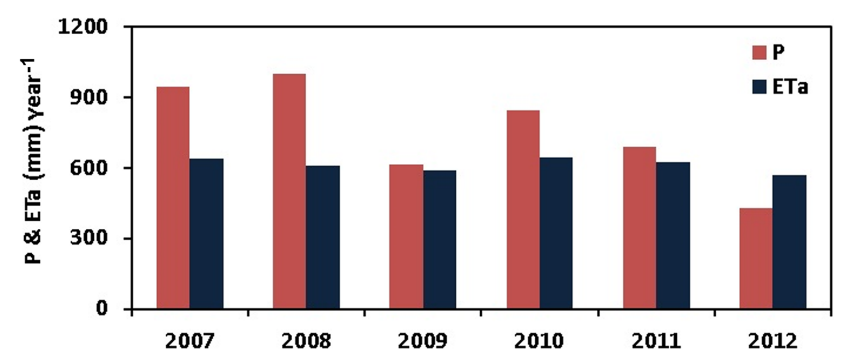

Figure 6. Annual precipitation $(P)$ and annual actual evapotranspiration $\left(\mathrm{ET}_{\mathrm{a}}\right)$ at the Mead rain-fed (US-Ne3) site.

In this research, we define RMSE values less than $0.03 \mathrm{~cm}^{3} \mathrm{~cm}^{-3}$ between observed and simulated SWC values as well matched and RMSE between 0.03 and $0.06 \mathrm{~cm}^{3} \mathrm{~cm}^{-3}$ as fairly well matched. We note the target error range of satellite SWC products (e.g., SMOS and SMAP) is less than $0.04 \mathrm{~cm}^{3} \mathrm{~cm}^{-3}$ (Entekhabi et al., 2010). Similar to previous studies (e.g., Jiménez-Martínez et al., 2009; Andreasen et al., 2013; Min et al., 2015; Wang et al., 2016), the results of all the performance criteria at TP locations show the capability of inverse modeling in estimation of soil hydraulic parameters. The results of the calibration period (2008-2010) indicate that the simulated and observed SWC values are in good agreement (i.e., well matched as defined above) throughout the entire period at most locations and depths (Fig. 7 and Table 3). In addition, the simulated and observed SWC data are fairly well matched at most locations and depths during the validation period (2011-2012), with notable differences during the second half of 2012 during the extreme drought conditions (Fig. 7 and Table 3). Reasons for this disagreement in the observed and simulated SWC data will be discussed in the following sections.

The results of inverse modeling using the CRNP data also indicate the feasibility of using these data to estimate effective soil hydraulic parameters (Fig. 8 and Table 4). Based 
Table 3. Goodness-of-fit measures for simulated and observed SWC data at different depths during the calibration period (2008-2010) and validation period (2011-2012) at TP locations. Note that we assume a good fit as an RMSE between 0 and $0.03 \mathrm{~cm}^{3} \mathrm{~cm}^{-3}$ and fair as between 0.03 and $0.06 \mathrm{~cm}^{3} \mathrm{~cm}^{-3}$.

\begin{tabular}{|c|c|c|c|c|c|c|c|c|c|}
\hline \multirow[t]{2}{*}{ Location } & \multirow{2}{*}{$\begin{array}{l}\text { Depth } \\
(\mathrm{cm})\end{array}$} & \multicolumn{4}{|c|}{ Calibration period (2008-2010) } & \multicolumn{4}{|c|}{ Validation period (2011-2012) } \\
\hline & & $R^{2}$ & $\begin{array}{r}\text { MAE } \\
\left(\mathrm{cm}^{3} \mathrm{~cm}^{3}\right)\end{array}$ & $\begin{array}{r}\text { RMSE } \\
\left(\mathrm{cm}^{3} \mathrm{~cm}^{3}\right)\end{array}$ & NSE & $R^{2}$ & $\begin{array}{r}\text { MAE } \\
\left(\mathrm{cm}^{3} \mathrm{~cm}^{-3}\right)\end{array}$ & $\begin{array}{r}\text { RMSE } \\
\left(\mathrm{cm}^{3} \mathrm{~cm}^{-3}\right)\end{array}$ & NSE \\
\hline \multirow[t]{4}{*}{ TP 1} & 10 & 0.542 & 0.024 & 0.036 & 0.533 & 0.532 & 0.016 & 0.033 & 0.503 \\
\hline & 25 & 0.742 & 0.014 & 0.022 & 0.739 & 0.716 & 0.029 & 0.040 & 0.486 \\
\hline & 50 & 0.409 & 0.013 & 0.023 & 0.407 & 0.603 & 0.041 & 0.074 & 0.157 \\
\hline & 100 & 0.352 & 0.015 & 0.022 & 0.343 & 0.419 & 0.027 & 0.038 & 0.358 \\
\hline \multirow[t]{4}{*}{ TP 2} & 10 & 0.330 & 0.044 & 0.066 & 0.305 & 0.287 & 0.047 & 0.061 & 0.052 \\
\hline & 25 & 0.623 & 0.010 & 0.020 & 0.604 & 0.718 & 0.038 & 0.055 & 0.135 \\
\hline & 50 & 0.551 & 0.015 & 0.026 & 0.074 & 0.683 & 0.040 & 0.055 & 0.202 \\
\hline & 100 & 0.424 & 0.019 & 0.027 & -2.055 & 0.344 & 0.048 & 0.073 & -0.473 \\
\hline \multirow[t]{4}{*}{ TP 3} & 10 & 0.269 & 0.034 & 0.051 & 0.256 & 0.534 & 0.086 & 0.102 & -4.265 \\
\hline & 25 & 0.512 & 0.011 & 0.017 & 0.509 & 0.852 & 0.010 & 0.015 & 0.793 \\
\hline & 50 & 0.549 & 0.015 & 0.023 & -0.214 & 0.658 & 0.022 & 0.033 & 0.652 \\
\hline & 100 & 0.238 & 0.018 & 0.029 & -3.156 & 0.669 & 0.018 & 0.025 & 0.178 \\
\hline \multirow[t]{4}{*}{ TP 4} & 10 & 0.412 & 0.029 & 0.044 & 0.406 & 0.580 & 0.051 & 0.071 & -0.116 \\
\hline & 25 & 0.434 & 0.016 & 0.025 & 0.350 & 0.594 & 0.029 & 0.042 & 0.490 \\
\hline & 50 & 0.151 & 0.009 & 0.015 & -13.400 & 0.443 & 0.041 & 0.073 & 0.036 \\
\hline & 100 & 0.001 & 0.013 & 0.021 & -12.058 & 0.292 & 0.026 & 0.039 & 0.238 \\
\hline
\end{tabular}

on the performance criteria (Table 4), the simulated data are fairly well matched with the observed SWC data during both the calibration and validation periods. Additional information from deeper soil probes or more complex modeling approaches, such as data assimilation techniques (Rosolem et al., 2012; Renzullo et al., 2014), may be needed to fully utilize the CRNP data for the entire growing season. However, this was beyond the scope of the current study and merits further investigation given the global network of CRNP (Zreda et al., 2012) dating back to $\sim 2011$.

Table 5 summarizes the optimized van Genuchten parameters for the four different depths of the four TP locations and the single layer for the CRNP location. The optimized parameters were then used to estimate $\mathrm{ET}_{\mathrm{a}}$ for the entire study period as an independent comparison to the $\mathrm{EC} \mathrm{ET}_{\mathrm{a}}$ data. The results of the $\mathrm{ET}_{\mathrm{a}}$ evaluation will be discussed in the next section. According to the simulation results (Table 5), in most of the soil layers, the TP 4 location results in lower $n$ and $K_{\mathrm{S}}$ values and higher $\theta_{\mathrm{r}}$ values than the other three locations (TPs 1-3), suggesting either underlying soil texture variability in the field or texture-dependent sensor sensitivity/calibration. As a validation for the simulation results, the publicly available Web Soil Survey data (http: //websoilsurvey.nrcs.usda.gov/) was used to explore whether the optimized van Genuchten parameters from the inverse modeling (Fig. 1b and Table 2) agreed qualitatively with the survey data. Based on the Web Soil Survey data, the soil at the TP 4 location contains higher clay percentage than the other locations. Meanwhile, the optimized parameters reflect the spatial pattern of soil texture in the field as shown by the Web Soil Survey data (e.g., lower $n$ and $K_{\mathrm{S}}$ values and higher $\theta_{\mathrm{r}}$ values at the TP 4 location with finer soil texture). Physically, finer-textured soils generally have lower $K_{\mathrm{S}}$ and higher $\theta_{\mathrm{r}}$ values (Carsel and Parrish, 1988). Moreover, the shape factor $n$ is indicative of pore size distributions of soils. In general, finer soils with smaller pore sizes tend to have lower $n$ values (Carsel and Parrish, 1988). The observed SWC at the TP 4 location is consistently higher than the average SWC of the other three locations (Fig. S4), which can be partly attributed to the higher $\theta_{\mathrm{r}}$ values at the TP 4 location (Wang and Franz, 2015). Overall, the obtained van Genuchten parameters from the inverse modeling are in qualitatively good agreement with the available spatial distribution of soil texture in the study field, indicating the capability of using inverse VZM to infer soil hydraulic properties. Further work on validating the Web Soil Survey data soil hydraulic property estimates is of general interest to the LSM community.

\subsection{Comparison of modeled ET $_{\mathbf{a}}$ with observed ET $_{\mathbf{a}}$}

Because a longer set of climatic data was available at the study site (as compared to SWC data), we used 2004-2006 as a spin-up period. Using the best-fit soil hydraulic parameters for the four TP locations and the single CRNP location, the Hydrus-1D model was then run in a forward mode to calculate $\mathrm{ET}_{\mathrm{a}}$ over the entire study period (2007-2012). The simulated daily $\mathrm{ET}_{\mathrm{a}}$ was then compared with the independent EC ET $\mathrm{a}_{\mathrm{a}}$ measurements using RMSE (Eq. 9) as the 
Table 4. Goodness-of-fit measures for simulated and observed SWC data during the calibration period (2012-2013) and validation period (2014) at the CRNP location.

\begin{tabular}{lrrrrr|rrrr}
\hline Location & Depth & \multicolumn{4}{c|}{ Calibration period (2012-2013) } & \multicolumn{4}{c}{ Validation period (2014) } \\
\cline { 3 - 9 } & & $R^{2}$ & $\begin{array}{r}\text { MAE } \\
\left(\mathrm{cm}^{3} \mathrm{~cm}^{-3}\right)\end{array}$ & $\begin{array}{r}\text { RMSE } \\
\left(\mathrm{cm}^{3} \mathrm{~cm}^{-3}\right)\end{array}$ & NSE & $R^{2}$ & $\begin{array}{r}\text { MAE } \\
\left(\mathrm{cm}^{3} \mathrm{~cm}^{-3}\right)\end{array}$ & $\begin{array}{r}\text { RMSE } \\
\left(\mathrm{cm}^{3} \mathrm{~cm}^{-3}\right)\end{array}$ & NSE \\
\hline CRNP & 10 & 0.497 & 0.018 & 0.027 & 0.456 & 0.192 & 0.020 & 0.032 & -0.310 \\
\hline
\end{tabular}
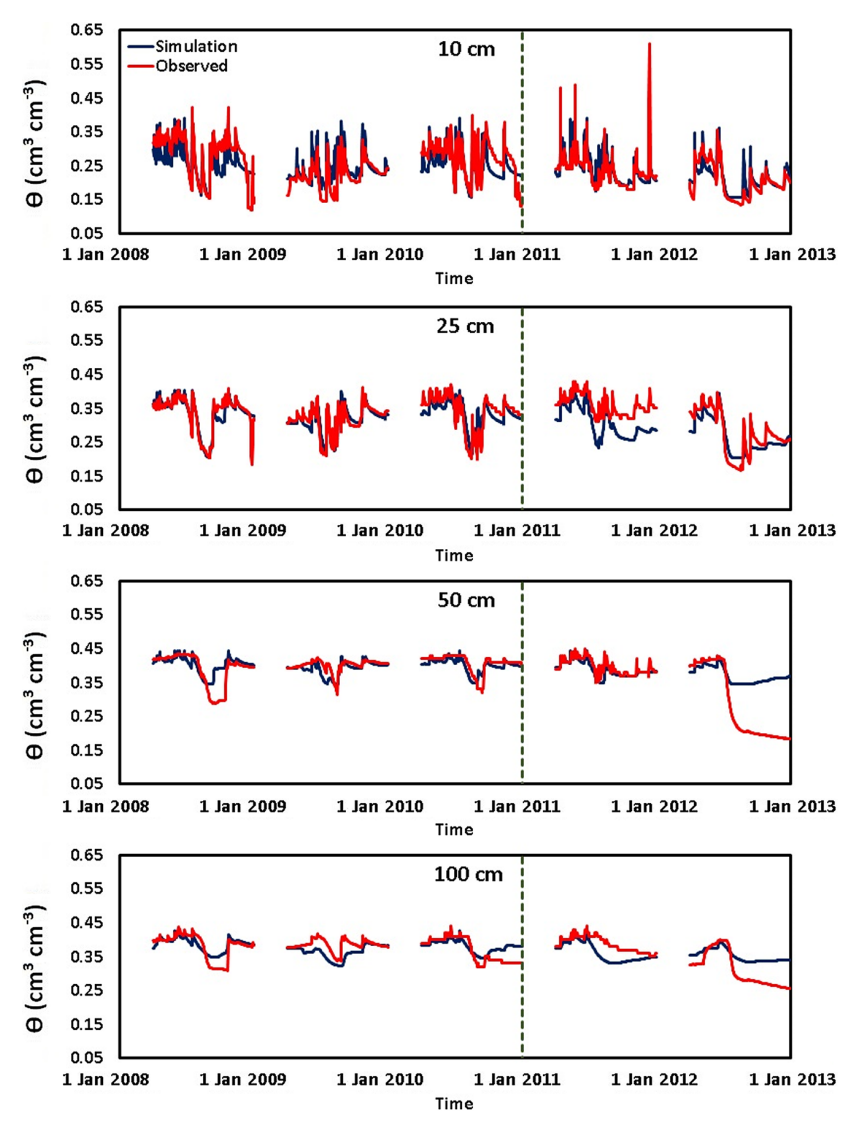

Figure 7. Daily observed and simulated $\operatorname{SWC}(\theta)$ during the calibration (2008-2010) and validation (2011-2012) periods at the TP 1 location. See supplemental figures for other comparisons.

evaluation criterion. In order to upscale $\mathrm{TP}_{\mathrm{ET}}$ estimation to the field/EC scale, we used the soil textural boundaries and areas defined by the Web Soil Survey data map to compute a weighted average $\mathrm{ET}_{\mathrm{a}}$. In this research, we consider RMSE values less than $1 \mathrm{~mm} \mathrm{day}^{-1}$ between observed and simulated $\mathrm{ET}_{\mathrm{a}}$ values as well matched and RMSE values between 1 and 1.2 as fairly well matched (Fig. 9 and Table 6). The performance criterion results indicate that the simulated daily $\mathrm{ET}_{\mathrm{a}}$ is in a better agreement with $\mathrm{EC} \mathrm{ET}_{\mathrm{a}}$ measurements at the TP 1-3 locations than at the TP 4 and CRNP locations (Table 6). However, based on the performance criteria from inverse modeling results and on the Web Soil Survey data, we conclude that spatial heterogeneity of soil texture in the

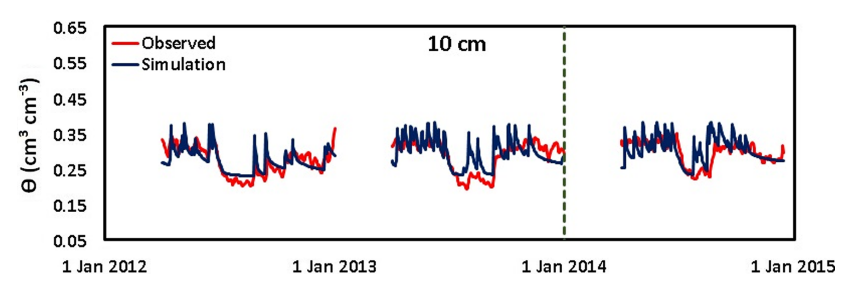

Figure 8. Daily observed and simulated SWC $(\theta)$ during the calibration (2012-2013) and validation (2014) periods at the location of the cosmic-ray neutron probe.

study field results in significant spatial variation in $\mathrm{ET}_{\mathrm{a}}$ rates across the field (e.g., less $\mathrm{ET}_{\mathrm{a}}$ occurs at the TP 4 location than in the other parts of the field). Here, smaller $\mathrm{ET}_{\mathrm{a}}$ rates at the TP 4 location are likely due to finer soil texture at this location, which makes it more difficult for the plant/roots to overcome potentials to extract water from the soil, thus leading to a lower $\mathrm{ET}_{\mathrm{a}}$ rate and greater plant stress. In addition, higher surface runoff can be expected at the TP 4 location due to finer-textured soils (as we observed during our field campaigns). According to the simulation results, the average surface runoff at the TP 4 location was about $44.8 \mathrm{~mm} \mathrm{yr}^{-1}$ from 2007 to 2012, while the average surface runoff at the other three locations (TPs 1-3) was around $10.6 \mathrm{~mm} \mathrm{yr}^{-1}$, which partially accounts for the lower $\mathrm{ET}_{\mathrm{a}}$ rates. We note that future work using historic yield maps may also be used to further elucidate the soil hydraulic property differences given the direct correlation between transpiration and yield.

Given that CRNPs have a limited observational depth and that only a single soil layer was optimized in the inverse model for the CRNP, one could expect the simulated daily $\mathrm{ET}_{\mathrm{a}}$ from the CRNP to have larger uncertainty. Here, we found an RMSE of $1.14 \mathrm{~mm} \mathrm{day}^{-1}$ using the CRNP versus $0.91 \mathrm{~mm} \mathrm{day}^{-1}$ for the upscaled TP locations. However, when the optimized soil parameters obtained from the CRNP data were used to estimate $\mathrm{ET}_{\mathrm{a}}$, the model did simulate daily $\mathrm{ET}_{\mathrm{a}}$ fairly well during both non-growing and growing seasons in comparison to the $\mathrm{EC} \mathrm{ET}_{\mathrm{a}}$ measurements.

On the annual scale, $\mathrm{ET}_{\mathrm{a}}$ measured by the EC tower accounted for $87 \%$ of annual $P$ recorded at the site during the study period (Fig. 6). Overall, the simulated annual $\mathrm{ET}_{\mathrm{a}}$ at all the TP and CRNP locations is comparable to the annual $\mathrm{ET}_{\mathrm{a}}$ measured by the EC tower, except during 2012 (Table 7), in which a severe drought occurred in the region. One explana- 
Table 5. Optimized van Genuchten parameters in different locations at the study site. Note that $95 \%$ confidence intervals are in parentheses.

\begin{tabular}{|c|c|c|c|c|c|c|c|}
\hline Location & $\begin{array}{r}\text { Depth } \\
(\mathrm{cm})\end{array}$ & $\begin{array}{r}\theta_{\mathrm{r}} \\
(-)\end{array}$ & $\begin{array}{r}\theta_{s} \\
(-)\end{array}$ & $\begin{array}{r}\alpha \\
\left(1 \mathrm{~cm}^{-1}\right)\end{array}$ & $\begin{array}{r}n \\
(-)\end{array}$ & $\begin{array}{r}K_{\mathrm{S}} \\
\left(\mathrm{cm} \mathrm{day}^{-1}\right)\end{array}$ & $\begin{array}{r}l \\
(-)\end{array}$ \\
\hline \multirow[t]{8}{*}{ TP 1} & \multirow[t]{2}{*}{$0-15$} & 0.134 & 0.423 & 0.027 & 1.475 & 8.119 & 0.546 \\
\hline & & $(0.130-0.137)$ & $(0.417-0.429)$ & $(0.026-0.027)$ & $(1.456-1.494)$ & $(7.965-8.273)$ & $(0.525-0.567)$ \\
\hline & \multirow[t]{2}{*}{$15-35$} & 0.136 & 0.408 & 0.007 & 1.345 & 11.540 & 0.480 \\
\hline & & $(0.132-0.141)$ & $(0.404-0.412)$ & $(0.007-0.007)$ & $(1.322-1.367)$ & (11.137-11.939) & $(0.466-0.494)$ \\
\hline & \multirow[t]{2}{*}{$35-75$} & 0.191 & 0.448 & 0.024 & 1.097 & 8.057 & 0.285 \\
\hline & & $(0.188-0.194)$ & $(0.443-0.453)$ & $(0.024-0.025)$ & $(1.088-1.105)$ & $(7.879-8.235)$ & $(0.278-0.292)$ \\
\hline & \multirow[t]{2}{*}{$75-175$} & 0.071 & 0.430 & 0.025 & 1.069 & 9.807 & 0.364 \\
\hline & & $(0.068-0.073)$ & $(0.424-0.436)$ & $(0.024-0.025)$ & (1.061-1.077) & $(9.540-10.073)$ & $(0.354-0.375)$ \\
\hline \multirow[t]{8}{*}{ TP 2} & \multirow[t]{2}{*}{$0-15$} & 0.211 & 0.446 & 0.027 & 1.567 & 8.120 & 1.000 \\
\hline & & $(0.195-0.227)$ & $(0.431-0.461)$ & $(0.018-0.035)$ & $(1.431-1.703)$ & $(4.660-11.580)$ & $(0.411-1.589)$ \\
\hline & \multirow[t]{2}{*}{$15-35$} & 0.197 & 0.434 & 0.006 & 1.191 & 8.655 & 0.022 \\
\hline & & $(0.105-0.289)$ & $(0.425-0.442)$ & $(0.003-0.008)$ & $(1.076-1.306)$ & (0.953-16.357) & $(-0.194-0.238)$ \\
\hline & \multirow[t]{2}{*}{$35-75$} & 0.110 & 0.424 & 0.015 & 1.239 & 4.605 & 0.723 \\
\hline & & $(0-0.258)$ & $(0.406-0.441)$ & $(0.007-0.023)$ & (1.040-1.438) & $(0-9.214)$ & $(-1.210-2.655)$ \\
\hline & \multirow[t]{2}{*}{$75-175$} & 0.109 & 0.408 & 0.020 & 1.302 & 6.780 & 0.000 \\
\hline & & $(0-0.275)$ & $(0.357-0.459)$ & $(0-0.044)$ & $(0.965-1.639)$ & $(0-20.523)$ & $(-0.045-0.045)$ \\
\hline \multirow[t]{8}{*}{ TP 3} & \multirow[t]{2}{*}{$0-15$} & 0.281 & 0.464 & 0.035 & 1.487 & 7.096 & 0.400 \\
\hline & & $(0.276-0.287)$ & $(0.463-0.465)$ & $(0.033-0.036)$ & $(1.446-1.528)$ & $(6.742-7.450)$ & $(0.385-0.416)$ \\
\hline & \multirow[t]{2}{*}{$15-35$} & 0.072 & 0.402 & 0.012 & 1.085 & 29.960 & 0.353 \\
\hline & & $(0.069-0.075)$ & $(0.398-0.407)$ & $(0.011-0.012)$ & (1.076-1.095) & $(28.470-31.457)$ & $(0.340-0.367)$ \\
\hline & \multirow[t]{2}{*}{$35-75$} & 0.081 & 0.498 & 0.037 & 1.128 & 24.440 & 0.527 \\
\hline & & $(0.076-0.087)$ & $(0.481-0.515)$ & $(0.034-0.039)$ & $(1.108-1.149)$ & $(22.013-26.872)$ & $(0.472-0.583)$ \\
\hline & \multirow[t]{2}{*}{$75-175$} & 0.085 & 0.500 & 0.039 & 1.147 & 17.540 & 0.496 \\
\hline & & $(0.077-0.092)$ & $(0.482-0.518)$ & $(0.036-0.042)$ & $(1.124-1.170)$ & (15.995-19.088) & $(0.454-0.539)$ \\
\hline \multirow[t]{8}{*}{ TP 4} & \multirow[t]{2}{*}{$0-15$} & 0.082 & 0.481 & 0.034 & 1.172 & 7.773 & 0.953 \\
\hline & & $(0.069-0.096)$ & $(0.474-0.489)$ & $(0.030-0.038)$ & $(1.158-1.186)$ & $(6.913-8.632)$ & $(0.772-1.133)$ \\
\hline & \multirow[t]{2}{*}{$15-35$} & 0.200 & 0.426 & 0.013 & 1.217 & 14.060 & 0.044 \\
\hline & & $(0.175-0.225)$ & $(0.420-0.433)$ & $(0.010-0.017)$ & $(1.173-1.262)$ & $(9.248-18.873)$ & $(0.027-0.061)$ \\
\hline & \multirow[t]{2}{*}{$35-75$} & 0.250 & 0.477 & 0.009 & 1.079 & 1.045 & 0.353 \\
\hline & & $(0.240-0.260)$ & $(0.472-0.481)$ & $(0.007-0.011)$ & (1.066-1.092) & $(0.952-1.138)$ & $(0.168-0.538)$ \\
\hline & \multirow[t]{2}{*}{$75-175$} & 0.200 & 0.487 & 0.012 & 1.070 & 1.454 & 0.985 \\
\hline & & $(0.185-0.214)$ & $(0.481-0.494)$ & $(0.009-0.014)$ & $(1.057-1.083)$ & $(1.146-1.762)$ & $(0.706-1.264)$ \\
\hline \multirow[t]{2}{*}{ CRNP } & \multirow[t]{2}{*}{$0-15$} & 0.100 & 0.392 & 0.019 & 1.054 & 6.931 & 0.547 \\
\hline & & $(0.098-0.103)$ & $(0.386-0.398)$ & $(0.018-0.019)$ & $(1.145-1.164)$ & $(6.786-7.076)$ & $(0.545-0.549)$ \\
\hline
\end{tabular}

Table 6. Goodness-of-fit measures for simulated and observed daily $\mathrm{ET}_{\mathrm{a}}$ during the simulation period (2007-2012) at the study site.

\begin{tabular}{lrrrr}
\hline Location & $\begin{array}{r}R^{2} \\
\left(\mathrm{~mm} \mathrm{day}^{-1}\right)\end{array}$ & $\begin{array}{r}\text { MAE } \\
\left(\mathrm{mm} \mathrm{day}^{-1}\right)\end{array}$ & RMSE & NSE \\
\hline $\mathrm{ET}_{\mathrm{p}}$ & 0.510 & 1.359 & 1.992 & 0.340 \\
$\mathrm{TP} 1$ & 0.644 & 0.696 & 1.062 & 0.618 \\
$\mathrm{TP}$ 2 & 0.754 & 0.610 & 0.907 & 0.746 \\
$\mathrm{TP} 3$ & 0.751 & 0.601 & 0.904 & 0.728 \\
$\mathrm{TP} 4$ & 0.365 & 0.878 & 1.387 & 0.168 \\
TPs' weighted & 0.742 & 0.599 & 0.911 & 0.714 \\
average & & & & \\
CRNP & 0.573 & 0.742 & 1.143 & 0.562 \\
\hline
\end{tabular}

tion is that the plants extract more water from deeper layers under extreme drought conditions than what we defined as a maximum rooting depth $(150 \mathrm{~cm}$ for maize and $120 \mathrm{~cm}$ for soybean) for the model, thus limiting the VZM ability to estimate $\mathrm{ET}_{\mathrm{a}}$ accurately during the drought year (2012). In fact, based on the $\mathrm{EC} \mathrm{ET}_{\mathrm{a}}$ measurements at the study site, there was just an $8.18 \%$ reduction in annual $\mathrm{ET}_{\mathrm{a}}$ in 2012 compared to the average of the other years (2007-2011), while there were 29.58 and $35.75 \%$ reductions in annual simulated $\mathrm{ET}_{\mathrm{a}}$ values, respectively, in upscaled TP and CRNP. This shows that although 2012 was a very dry year, the plants probably found most of the needed water by extracting water from deeper soil reservoirs. As previously mentioned, we defined a maximum rooting depth for the model that could greatly impact the results. To further illustrate this point, a 

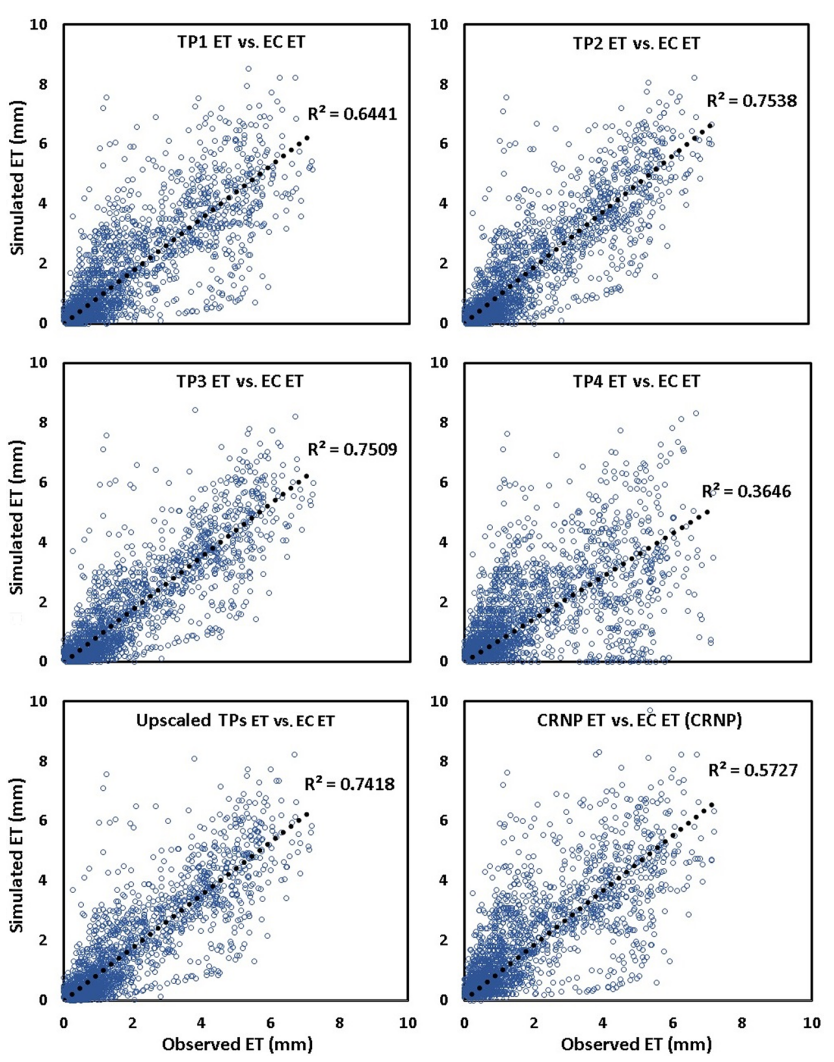

Figure 9. Simulated daily $\mathrm{ET}_{\mathrm{a}}$ versus observed daily $\mathrm{ET}_{\mathrm{a}}$ in different locations at the study site (2007-2012).

sensitivity analysis was performed on the maximum rooting depth and presented in the following section. However, we note that given the fact that $\mathrm{EC} \mathrm{ET}_{\mathrm{a}}$ estimation can have up to $20 \%$ uncertainty (Massman and Lee, 2002, and Hollineger and Richardson, 2005), and accounting for the natural spatial variability of $\mathrm{ET}_{\mathrm{a}}$ due to soil texture and root depth growth uncertainties, the various $\mathrm{ET}_{\mathrm{a}}$ estimation techniques performed fairly well. In fact, it is difficult to identify which $\mathrm{ET}_{\mathrm{a}}$ estimation method is the most accurate method. These results are consistent with the concept of equifinality in hydrologic modeling given the complexity of natural systems (Beven and Freer, 2001). Moreover, the findings here are consistent with Nearing et al. (2016) who showed that information lost in model parameters greatly affects the soil moisture comparisons against a benchmark. However, soil parameterization was less important in the loss of information for the comparisons of ET/latent energy against a benchmark. Fully resolving these issues remains a key challenge to the land surface modeling community and the model's ability to make accurate predictions (Best et al., 2015). The following section provides a detailed sensitivity analysis of the soil hydraulic parameters and root depth growth functions in order to begin to understand the sources of error in estimating $\mathrm{ET}_{\mathrm{a}}$ from SWC monitoring networks.

\subsection{Sensitivity analysis of soil hydraulic parameters and rooting depth}

In this research, we compared simulated $\mathrm{ET}_{\mathrm{a}}$ with the measured $\mathrm{EC} \mathrm{ET}_{\mathrm{a}}$. As expected, some discrepancies between simulated and measured $\mathrm{ET}_{\mathrm{a}}$ values existed. In order to begin to understand the key sources of error, we performed a set of sensitivity analysis experiments on the estimated soil hydraulic parameters. Building on Wang et al. (2009b), a sensitivity analysis for a single homogeneous soil layer (6 parameters) and a four-layer soil profile (24 parameters) was performed over the study period (2007-2012). Here, we performed a preliminary sensitivity analysis by changing a single soil hydraulic parameter one at a time while keeping the other parameters constant (i.e., at the average value). Figure 10 illustrates the sensitivity results on simulated $\mathrm{ET}_{\mathrm{a}}$, indicating that the soil hydraulic parameters have a range of sensitivities with tortuosity $(l)$ being the least. We found that $n$ and $\alpha$ were the most sensitive, particularly in the shallowest soil layer. This sensitivity to the shallowest soil layer provides an opportunity to use the CRNP observations, particularly in the early growing season (i.e., when evaporation dominates latent energy flux), to help constrain estimates of $n$ and $\alpha$. As the crop continues to develop (and transpiration contributes a relatively larger component of latent energy), additional information about deeper soil layers should be used to estimate soil hydraulic parameters or perform data assimilation. Moreover, the CRNP may be useful in helping constrain and parameterize soil hydraulic functions in simpler evaporation models widely used in remote sensing (see Allen et al., 2007) and crop modeling (see Allen et al., 1998).

Following the sensitivity analysis, we repeated the optimization experiment using only $\alpha, n$, and $K_{\mathrm{S}}$, and used model default estimates for the other parameters in each layer. We found that the RMSE values were significantly higher (1.511 vs. $0.911 \mathrm{~mm} \mathrm{day}^{-1}$ ) than when considering all 24 parameters. We suspect, given the high correlation between soil hydraulic parameters (Carsel and Parrish, 1988), that fixing certain parameters leads to a degradation in overall performance. We suggest that further sensitivity analyses, in particular changing multiple parameters simultaneously or using multiple objective functions, be used to fully understand model behavior (see Bastidas et al., 1999 and Rosolem et al., 2012).

A sensitivity analysis of $\mathrm{ET}_{\mathrm{a}}$ by varying rooting depth is summarized in Fig. 11. As would be expected with increasing rooting depth, higher $\mathrm{ET}_{\mathrm{a}}$ occurred. In addition, Fig. 11 illustrates a decreasing RMSE against EC observations for increases up to $200 \%$. Again, it is unclear if the EC observations are biased high or if in fact rooting depths are much greater than typically considered in these models. The high observed EC values in the drought year of 2012 indicate that roots likely take up water from below the $1 \mathrm{~m}$ observations. Certainly the results shown here further indicate the importance of root water uptake parameters in VZMs and LSMs, 
Table 7. Summary of simulated yearly and average actual evapotranspiration $\left(\mathrm{ET}_{\mathrm{a}}\right)(\mathrm{mm})$ and observed yearly and average actual evapotranspiration $\left(\mathrm{ET}_{\mathrm{a}}\right)(\mathrm{mm})$ from the eddy covariance tower from 2007 to 2012.

\begin{tabular}{lrrrrrrr}
\hline Location & \multicolumn{7}{c}{ Year } \\
\cline { 2 - 8 } & 2007 & 2008 & 2009 & 2010 & 2011 & 2012 & Average \\
\hline ET $_{\mathrm{p}}$ & 1048.5 & 987.9 & 989.4 & 1011.5 & 1025.7 & 1326.7 & 1064.9 \\
EC & 656.8 & 608.4 & 589.7 & 646.1 & 622.2 & 570.1 & 612.5 \\
TP 1 & 646.1 & 629.0 & 559.8 & 642.1 & 573.9 & 415.5 & 579.5 \\
TP 2 & 614.3 & 598.4 & 576.7 & 620.5 & 576.9 & 429.5 & 574.7 \\
TP 3 & 529.0 & 556.1 & 556.4 & 590.4 & 549.8 & 405.2 & 545.4 \\
TP 4 & 652.2 & 576.1 & 529.9 & 677.3 & 458.2 & 381.2 & 525.3 \\
Upscaled TPs & 613.9 & 564.1 & 556.3 & 600.3 & 547.7 & 405.9 & 548.0 \\
CRNP & 745.3 & 707.1 & 603.0 & 721.8 & 642.2 & 439.3 & 643.1 \\
\hline
\end{tabular}
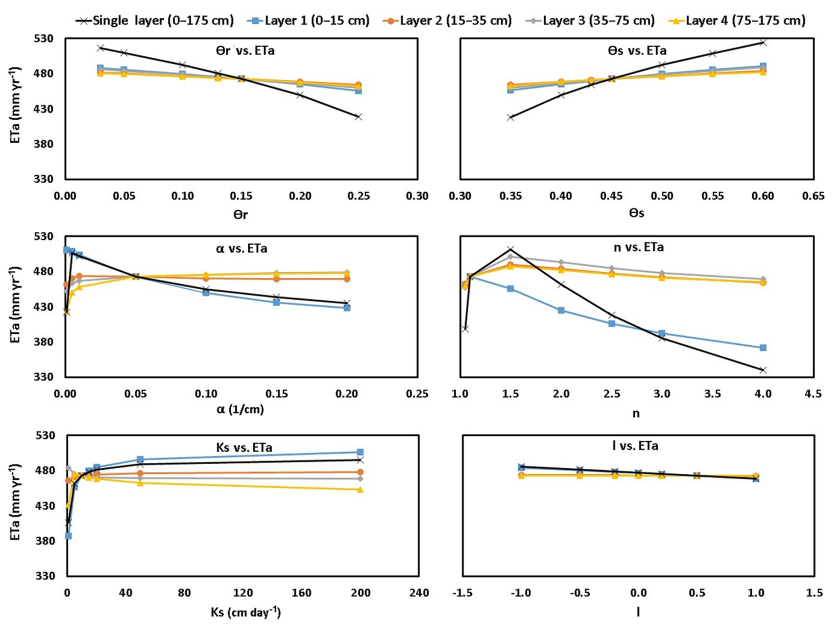

Figure 10. Sensitivity analysis of the effect of soil hydraulic parameters on average annual $\mathrm{ET}_{\mathrm{a}}$ values (2007-2012) for a single homogeneous soil layer (6 parameters) and for a four-layer soil profile (24 parameters)

even in homogeneous annual cropping systems. While it is beyond the scope of this paper, we refer the reader to the growing literature on the importance of root water uptake parameters on hydrologic fluxes (see Schymanski et al. 2008 and Guswa, 2012).

\subsection{Applications and limitations of the vadose zone modeling framework}

Given their simplicity and the widespread availability of ground data, $\mathrm{ET}_{\mathrm{r}}$ and $K_{\mathrm{c}}$ values are often used in a wide variety of applications to estimate $\mathrm{ET}_{\mathrm{p}}$ and thus approximate $\mathrm{ET}_{\mathrm{a}}$. It is well known that $\mathrm{SWC}$ is a limiting factor affecting the assumption that $\mathrm{ET}_{\mathrm{p}} \sim \mathrm{ET}_{\mathrm{a}}$. On the other hand, we know that SWC observations are local in nature and not necessarily representative of $\mathrm{ET}_{\mathrm{a}}$ footprint estimates. The key questions include what the value of SWC observations is, how many profiles should be installed in a footprint, and which
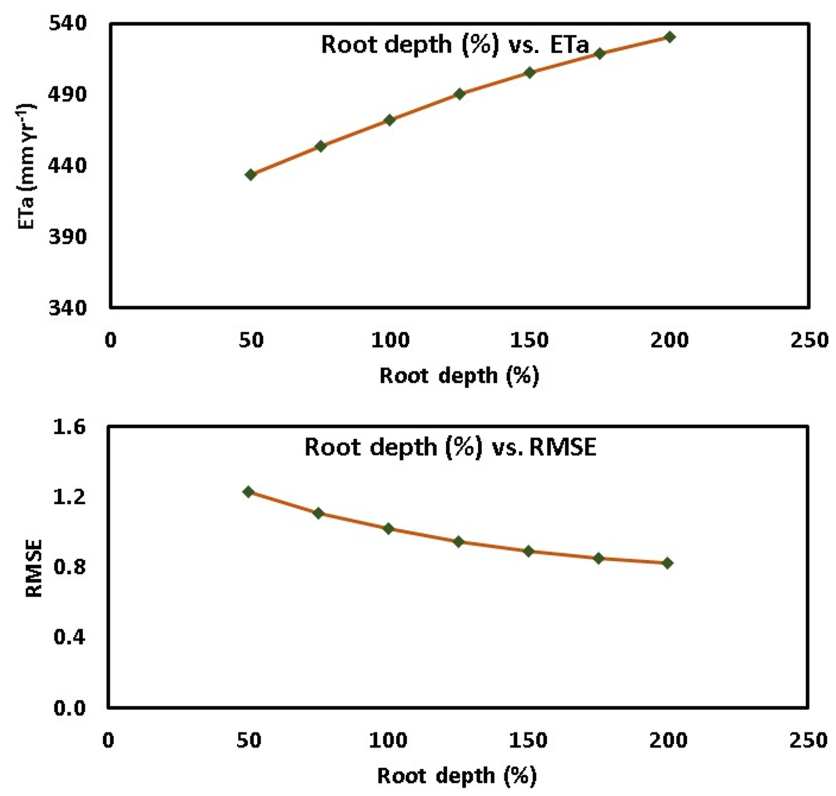

Figure 11. Sensitivity analysis of the effect of root depth on $\mathrm{ET}_{\mathrm{a}}$ estimation for a single homogeneous soil layer profile. Note that root depth is shown in terms of percent depth, as it is dynamic over the growing period.

depths should be used to constrain estimates of fluxes. The well-instrumented and long-term study presented here allows us to start to answer these key questions. First, we find that $\mathrm{ET}_{\mathrm{p}}$ has an average annual value of $1064.9 \mathrm{~mm}$ as compared to EC at $612.5 \mathrm{~mm}$ (Table 7). By including individual SWC profiles (TP 1-4) and the CRNP in the VZM framework, we are able to constrain our estimate of $\mathrm{ET}_{\mathrm{a}}$ to between 525.3 and $643.1 \mathrm{~mm}$ and reduce $\mathrm{ET}_{\mathrm{a}}$ RMSE from 1.992 to around $1 \mathrm{~mm} \mathrm{day}^{-1}$ (Table 6). In addition, a range of soil hydraulic parameters for each depth and spatially averaged top layer can be estimated to help better constrain recharge fluxes simultaneously. Given the principle of equifinality in hydrologic systems, the VZM framework may lead to equally reasonable estimates of parameters, which is a limitation of the 
method and LSMs in general. Based on our sensitivity analysis (Fig. 10), the key parameters of $\alpha$ and $n$ may greatly affect $\mathrm{ET}_{\mathrm{a}}$.

Although sparsely distributed, widespread state, national, and global meteorological observations paired with SWC profiles (Xia et al., 2015) and the VZM framework provide an opportunity to better constrain $\mathrm{ET}_{\mathrm{a}}$ and local soil hydraulic functions. Moreover, where multiple SWC profile information is available, a range of $\mathrm{ET}_{\mathrm{a}}$ and soil hydraulic parameters can be estimated and thus considered in LSM data assimilation frameworks. The combination of basic metrological observations with a CRNP in the VZM framework further allows for estimates of upscaled soil hydraulic parameters with similar estimates of $\mathrm{ET}_{\mathrm{a}}$ as found with individual SWC profiles. Moving forward, combining CRNP with deeper SWC observations from point sensors seems to be a reasonable strategy in order to average the inherent SWC variability in the near surface yet provide SWC constraints at depth, particularly as annual crops develop over the growing season.

\section{Conclusions}

In this study, the feasibility of using inverse vadose zone modeling for field-scale $\mathrm{ET}_{\mathrm{a}}$ estimation was explored at an agricultural site in eastern Nebraska. Both point SWC sensors (TPs) and area-average techniques (CRNPs) were explored. This methodology has been successfully used for estimates of groundwater recharge but it was critical to assess the performance of other components of the water balance such as $\mathrm{ET}_{\mathrm{a}}$. The results indicate reasonable estimates of daily and annual $\mathrm{ET}_{\mathrm{a}}$ but with varied soil hydraulic function parameterizations. The varied soil hydraulic parameters were expected given the heterogeneity of soil texture at the site and consistent with the principle of equifinality in hydrologic systems. We note that while this study focused on one particular site, the framework can be easily applied to other networks of SWC monitoring across the globe (Xia et al., 2015). The value-added products of groundwater recharge and $\mathrm{ET}_{\mathrm{a}}$ flux from the SWC monitoring networks will provide additional and more robust benchmarks for the validation of LSM that continues to improve their forecast skill.

Data availability. The climatic and EC data used in this research can be found at http://ameriflux.lbl.gov/. The TP SWC and LAI data in the study site are provided by Andrew Suyker and CRNP SWC are provided by Trenton E. Franz, and both sets of data can be requested directly from the authors. The US soil taxonomy information is provided by Soil Survey Staff and is available online at http://websoilsurvey.nrcs.usda.gov/. The remaining datasets are provided in the Supplement associated with this paper.

The Supplement related to this article is available online at doi:10.5194/hess-21-1263-2017-supplement.
Competing interests. The authors declare that they have no conflict of interest.

Acknowledgements. This research is supported financially by the Daugherty Water for Food Global Institute at the University of Nebraska, NSF EPSCoR FIRST Award, the Cold Regions Research Engineering Laboratory through the Great Plains CESU, and an USGS104b grant. We sincerely appreciate the support and the use of facilities and equipment provided by the Center for Advanced Land Management Information Technologies, School of Natural Resources and data from Carbon Sequestration Program, the University of Nebraska-Lincoln. T.E. Franz would like to thank Eric Wood for his inspiring research and teaching career. There is no doubt that the skills T.E. Franz learned while at Princeton in the formal course work, seminars, and discussions with Eric will serve him well in his own career.

Edited by: M. McCabe

Reviewed by: R. B. Jana and two anonymous referees

\section{References}

Allen, R. G., Pereira, L. S., Raes, D., and Smith, M.: Crop evapotranspiration-guidelines for computing crop water requirements-FAO irrigation and drainage paper 56, FAO, Rome, 300, D05109, 1998.

Allen, R. G., Tasumi, M., and Trezza, R.: Satellite-based energy balance for mapping evapotranspiration with internalized calibration (METRIC)-Model, J. Irrig. Drain. E.-ASCE, 133, 380-394, 2007.

Anayah, F. M. and Kaluarachchi, J. J.: Improving the complementary methods to estimate evapotranspiration under diverse climatic and physical conditions, Hydrol. Earth Syst. Sci., 18, 2049-2064, doi:10.5194/hess-18-2049-2014, 2014.

Andreasen, M., Andreasen, L. A., Jensen, K. H., Sonnenborg, T. O., and Bircher, S.: Estimation of regional groundwater recharge using data from a distributed soil moisture network, Vadose Zone J., 12, doi:10.2136/vzj2013.01.0035, 2013.

ASCE-EWRI: The ASCE Standardized reference evapotranspiration equation. ASCE-EWRI Standardization of Reference Evapotranspiration Task Comm. Report, ASCE Bookstore, ISBN 078440805, Stock Number 40805, 216 pp., 2005.

Baatz, R., Bogena, H. R., Franssen, H. J. H., Huisman, J. A., Qu, W., Montzka, C., and Vereecken, H.: Calibration of a catchment scale cosmic-ray probe network: A comparison of three parameterization methods, J. Hydrol., 516, 231-244, 2014.

Baldocchi, D., Falge, E., Gu, L., and Olson, R.: FLUXNET: A new tool to study the temporal and spatial variability of ecosystemscale carbon dioxide, water vapor, and energy flux densities, B. Am. Meteorol. Soc., 82, 2415-2434, 2001.

Baldocchi, D. D., Hincks, B. B., and Meyers, T. P.: Measuring biosphere-atmosphere exchanges of biologically related gases with micrometeorological methods, Ecology, 1331-1340, 1988.

Bastidas, L. A., Gupta, H. V., Sorooshian, S., Shuttleworth, W. J., and Yang, Z. L.:. Sensitivity analysis of a land surface scheme using multicriteria methods, J. Geophys. Res.-Atmos., 104, 1948119490, doi:10.1029/1999jd900155, 1999. 
Best, M. J., Abramowitz, G., Johnson, H. R., Pitman, A. J., Balsamo, G., Boone, A., Cuntz, M., Decharme, B., Dirmeyer, P. A., Dong, J., and Ek, M.: The plumbing of land surface models: Benchmarking model performance, J. Hydrometeorol., 16, 1425-1442, 2015.

Beven, K. and Freer, J.: Equifinality, data assimilation, and uncertainty estimation in mechanistic modelling of complex environmental systems using the GLUE methodology, J. Hydrol., 249, 11-29, 2001.

Bogena, H., Huisman, J., Baatz, R., Hendricks Franssen, H., and Vereecken, H.: Accuracy of the cosmic-ray soil water content probe in humid forest ecosystems: The worst case scenario, Water Resour. Res., 49, 5778-5791, 2013.

Carsel, R. F. and Parrish, R. S.: Developing joint probability distributions of soil water retention characteristics, Water Resour. Res., 24, 755-769, 1988.

Chaney, N. W., Wood, E. F., McBratney, A. B., Hempel, J. W., Nauman, T. W., Brungard, C. W., and Odgers, N. P: POLARIS: A 30-meter probabilistic soil series map of the contiguous United States, Geoderma, 274, 54-67, 2016.

Chemin, Y. and Alexandridis, T.: Improving spatial resolution of ET seasonal for irrigated rice in Zhanghe, china. Paper Presented at the 22nd Asian Conference on Remote Sensing, 5 pp., 2001.

Desilets, D. and Zreda, M.: Footprint diameter for a cosmic-ray soil moisture probe: Theory and monte carlo simulations, Water Resour. Res., 49, 3566-3575, 2013.

Entekhabi, D., Njoku, E. G., O’Neill, P. E., Kellogg, K. H., Crow, W. T., Edelstein, W. N., Entin, J. K., Goodman, S. D., Jackson, T. J., Johnson, J., Kimball, J., Piepmeier, J. R., Koster, R. D., Martin, N., McDonald, K. C., Moghaddam, M., Moran, S., Reichle, R., Shi, J. C., Spencer, M. W., Thurman, S. W., Tsang, L., and Van Zyl, J.: The Soil Moisture Active Passive (SMAP) Mission, P. IEEE, 98, 704-716, doi:10.1109/jproc.2010.2043918, 2010.

Feddes, R. A., Kowalik, P. J., and Zaradny, H.: Simulation of field water use and crop yield, Centre for Agricultural Publishing and Documentation, 1978.

Franz, T. E., Zreda, M., Ferre, T. P. A., Rosolem, R., Zweck, C., Stillman, S., Zeng, X., and Shuttleworth, W. J: Measurement depth of the cosmic ray soil moisture probe affected by hydrogen from various sources, Water Resour. Res., 48, W08515, doi:10.1029/2012WR011871, 2012.

Franz, T. E., Wang, T., Avery, W., Finkenbiner, C., and Brocca, L.: Combined analysis of soil moisture measurements from roving and fixed cosmic ray neutron probes for multiscale real-time monitoring, Geophys. Res. Lett., 42, 3389-3396, 2015.

Franz, T. E., Wahbi, A., Vreugdenhil, M., Weltin, G., Heng, L., Oismueller, M., Strauss, P., Dercon, G., and Desilets, D.: Using cosmic-ray neutron probes to monitor landscape scale soil water content in mixed land use agricultural systems, Applied and Environmental Soil Science, 2016, 4323742, doi:10.1155/2016/4323742, 2016.

Galleguillos, M., Jacob, F., Prévot, L., Lagacherie, P., and Liang, S.: Mapping daily evapotranspiration over a Mediterranean vineyard watershed, IEEE Geosci. Remote S., 8, 168-172, 2011.

Glenn, E. P., Huete, A. R., Nagler, P. L., Hirschboeck, K. K., and Brown, P.: Integrating remote sensing and ground methods to estimate evapotranspiration. Crit. Rev. Plant Sci., 26, 139-168, 2007
Guswa, A. J.: Canopy vs. Roots: Production and Destruction of Variability in Soil Moisture and Hydrologic Fluxes, Vadose Zone J., 11, doi:10.2136/vzj2011.0159, 2012.

Hawdon, A., McJannet, D., and Wallace, J.: Calibration and correction procedures for cosmic-ray neutron soil moisture probes located across Australia, Water Resour. Res., 50, 5029-5043, 2014.

Hoffman, G. J. and van Genuchten, M. T: Soil properties and efficient water use: water management for salinity control, in: Taylor, H. M., Jordan, W. R., and Sinclair, T. R., Limitations and Efficient Water Use in Crop Production, Am. Soc. Of Agron., Madison, WI, 73-85, 1983.

Hollinger, D. Y. and Richardson, A. D.: Uncertainty in eddy covariance measurements and its application to physiological models, Tree Physiol., 25, 873-885, 2005.

Hopmans, J. W. and Šimunek, J.: Review of inverse estimation of soil hydraulic properties, in: Proceedings of the International Workshop Characterization and Measurement of Hydraulic Properties of Unsaturated Porous Media, edited by: van Genuchten, M. T., Leij, F. J., and Wu, L., University of California, Riverside, 643-659, 1999.

Irmak, S.: Nebraska water and energy flux measurement, modeling, and research network (NEBFLUX), T. ASABE, 53, 1097-1115, 2010.

Izadifar, Z. and Elshorbagy, A.: Prediction of hourly actual evapotranspiration using neural networks, genetic programming, and statistical models, Hydrol. Process., 24, 3413-3425, 2010.

Jiménez-Martínez, J., Skaggs, T., Van Genuchten, M. T., and Candela, L.: A root zone modelling approach to estimating groundwater recharge from irrigated areas, J. Hydrol., 367, 138-149, 2009.

Kalfas, J. L., Xiao, X., Vanegas, D. X., Verma, S. B., and Suyker, A. E.: Modeling gross primary production of irrigated and rainfed maize using MODIS imagery and $\mathrm{CO}_{2}$ flux tower data, Agr. Forest Meteorol., 151, 1514-1528, 2011.

Kjaersgaard, J., Allen, R., Trezza, R., Robison, C., Oliveira, A., Dhungel, R., and Kra, E: Filling satellite image cloud gaps to create complete images of evapotranspiration, IAHS-AISH Publication, 102-105, 2012.

Köhli, M., Schrön, M., Zreda, M., Schmidt, U., Dietrich, P., and Zacharias, S.: Footprint characteristics revised for field-scale soil moisture monitoring with cosmic-ray neutrons, Water Resour. Res., 51, 5772-5790, 2015.

Li, Z. L., Tang, R., Wan, Z., Bi, Y., Zhou, C., Tang, B., Yan, G., and Zhang, X.: A review of current methodologies for regional evapotranspiration estimation from remotely sensed data, Sensors, 9 , 3801-3853, 2009.

Lv, L., Franz, T. E., Robinson, D. A., and Jones, S. B.: Measured and modeled soil moisture compared with cosmic-ray neutron probe estimates in a mixed forest, Vadose Zone J., 13, doi:10.2136/vzj2014.06.0077, 2014.

Maidment, D. R.: Handbook of hydrology, McGraw-Hill Inc., 1992.

Massman, W. and Lee, X.: Eddy covariance flux corrections and uncertainties in long-term studies of carbon and energy exchanges, Agr. Forest Meteorol., 113, 121-144, 2002.

McMaster, G. S. and Wilhelm, W.: Growing degree-days: One equation, two interpretations, Agr. Forest Meteorol., 87, 291-300, 1997.

Min, L., Shen, Y., and Pei, H.: Estimating groundwater recharge using deep vadose zone data under typical irrigated cropland in 
the piedmont region of the north china plain, J. Hydrol., 527, 305-315, 2015.

Mualem, Y.: A new model for predicting the hydraulic conductivity of unsaturated porous media, Water Resour. Res., 12, 513-522, 1976.

Nearing, G. S., Mocko, D. M., Peters-Lidard, C. D., Kumar, S. V., and Xia, Y.: Benchmarking NLDAS-2 soil moisture and evapotranspiration to separate uncertainty contributions, J. Hydrometeorol., 17, 745-759, 2016.

Renzullo, L. J., Van Dijk, A. I. J. M., Perraud, J. M., Collins, D., Henderson, B., Jin, H., Smith, A. B., and McJannet, D. L.: Continental satellite soil moisture data assimilation improves rootzone moisture analysis for water resources assessment, J. Hydrol., 519, 2747-2762, 2014.

Ries, F., Lange, J., Schmidt, S., Puhlmann, H., and Sauter, M.: Recharge estimation and soil moisture dynamics in a Mediterranean, semi-arid karst region, Hydrol. Earth Syst. Sci., 19, 1439-1456, doi:10.5194/hess-19-1439-2015, 2015.

Ritter, A., Hupet, F., Muñoz-Carpena, R., Lambot, S., and Vanclooster, M.: Using inverse methods for estimating soil hydraulic properties from field data as an alternative to direct methods, Agr. Water Manage., 59, 77-96, 2003.

Rosolem, R., Gupta, H. V., Shuttleworth, W. J., Zeng, X. B., and de Goncalves, L. G. G.: A fully multiple-criteria implementation of the Sobol' method for parameter sensitivity analysis, J. Geophys. Res.-Atmos., 117, D07103, doi:10.1029/2011jd016355, 2012.

Schymanski, S. J., Sivapalan, M., Roderick, M. L., Beringer, J., and Hutley, L. B.: An optimality-based model of the coupled soil moisture and root dynamics, Hydrol. Earth Syst. Sci., 12, 913932, doi:10.5194/hess-12-913-2008, 2008.

Senay, G. B., Budde, M. E., and Verdin, J. P.: Enhancing the simplified surface energy balance (SSEB) approach for estimating landscape ET: Validation with the METRIC model, Agr. Water Manage., 98, 606-618, 2011.

Šimunek, J., Šejna, M., Saito, H., Sakai, M., and van Genuchten, M. T.: The HYDRUS-1D Software Package for Simulating the OneDimensional Movement of Water,Heat, and Multiple Solutes in Variably-Saturated Media, Version 4.17.Department of Environmental Sciences, University of California Riverside, Riverside, California, USA, 307 pp., 2013.

Soil Survey Staff: Natural Resources Conservation Service: United States Department of Agriculture, Web Soil Survey, available at: http://websoilsurvey.nrcs.usda.gov/, last access: July, 2016.

Stoy, P.: Evapotranspiration and energy flux observations from a global tower network with a critical analysis of uncertainties, AGU Fall Meeting Abstracts, http://adsabs.harvard.edu/abs/ 2012AGUFM.B22A..06S (last access: 28 February 2017), 2012.

Suyker, A. E. and Verma, S. B.: Interannual water vapor and energy exchange in an irrigated maize-based agroecosystem, Agr. Forest Meteorol., 148, 417-427, 2008.

Suyker, A. E. and Verma, S. B.: Evapotranspiration of irrigated and rainfed maize-soybean cropping systems, Agr. Forest Meteorol., 149, 443-452, 2009.

Suyker, A., Verma, S., Burba, G., Arkebauer, T., Walters, D., and Hubbard, K.: Growing season carbon dioxide exchange in irrigated and rainfed maize, Agri. Forest Meteorol., 124, 1-13, 2004.

Suyker, A. E., Verma, S. B., Burba, G. G., and Arkebauer, T. J.: Gross primary production and ecosystem respiration of irrigated maize and irrigated soybean during a growing season, Agr. Forest Meteorol., 131, 180-190, 2005.

Turkeltaub, T., Kurtzman, D., Bel, G., and Dahan, O.: Examination of groundwater recharge with a calibrated/validated flow model of the deep vadose zone, J. Hydrol., 522, 618-627, 2015.

Twarakavi, N. K. C., Šimůnek, J., and Seo, S.: Evaluating interactions between groundwater and vadose zone using the HYDRUSbased flow package for MODFLOW, Vadose Zone J., 7, 757768, 2008.

van Genuchten, M. T.: A closed-form equation for predicting the hydraulic conductivity of unsaturated soils, Soil Sci. Soc. Am. J., 44, 892-898, 1980.

Verma, S. B., Dobermann, A., Cassman, K. G., Walters, D. T., Knops, J. M., Arkebauer, T. J., Suyker, A. E., Burba, G. G., Amos, B., Yang, H., and Ginting, D.: Annual carbon dioxide exchange in irrigated and rainfed maize-based agroecosystems, Agr. Forest Meteorol., 131, 77-96, 2005.

Wang, T. and Franz, T. E.: Field observations of regional controls of soil hydraulic properties on soil moisture spatial variability in different climate zones, Vadose Zone J., 14, doi:10.2136/vzj2015.02.0032, 2015.

Wang, T., Istanbulluoglu, E., Lenters, J., and Scott, D.: On the role of groundwater and soil texture in the regional water balance: An investigation of the Nebraska sand hills, USA, Water Resour. Res., 45, W10413, doi:10.1029/2009WR007733, 2009a.

Wang, T., Zlotnik, V. A., Šimunek, J., and Schaap, M. G.: Using pedotransfer functions in vadose zone models for estimating groundwater recharge in semiarid regions, Water Resour. Res., 45, W04412, doi:10.1029/2008WR006903, 2009b.

Wang, T., Franz, T. E., and Zlotnik, V. A.: Controls of soil hydraulic characteristics on modeling groundwater recharge under different climatic conditions, J. Hydrol., 521, 470-481, 2015.

Wang, T., Franz, T. E., Yue, W., Szilagyi, J., Zlotnik, V. A., You, J., Chen, X., Shulski, M. D., and Young, A.: Feasibility analysis of using inverse modeling for estimating natural groundwater recharge from a large-scale soil moisture monitoring network, J. Hydrol., 533, 250-265, 2016.

Wolf, A., Saliendra, N., Akshalov, K., Johnson, D. A., and Laca, E.: Effects of different eddy covariance correction schemes on energy balance closure and comparisons with the modified bowen ratio system, Agr. Forest Meteorol., 148, 942-952, 2008.

Wood, E. F., Roundy, J. K., Troy, T. J., Van Beek, L. P. H., Bierkens, M. F., Blyth, E., de Roo, A., Döll, P., Ek, M., Famiglietti, J., and Gochis, D.: Hyperresolution global land surface modeling: Meeting a grand challenge for monitoring earth's terrestrial water, Water Resour. Res., 47, W05301, doi:10.1029/2010WR010090, 2011.

Wösten, J., Pachepsky, Y. A., and Rawls, W.: Pedotransfer functions: Bridging the gap between available basic soil data and missing soil hydraulic characteristics, J. Hydrol., 251, 123-150, 2001.

Xia, Y., Ek, M. B., Wu, Y., Ford, T., and Quiring, S. M.: Comparison of NLDAS-2 simulated and NASMD observed daily soil moisture. Part I: Comparison and analysis, J. Hydrometeorol., 16, 1962-1980, 2015.

Xie, Y., Sha, Z., and Yu, M.: Remote sensing imagery in vegetation mapping: A review, J. Plant Ecol., 1, 9-23, 2008. 
Yang, H., Dobermann, A., Cassman, K. G., and Walters, D. T.: Hybrid-maize. A Simulation Model for Corn Growth and Yield, Nebraska Cooperative Extension CD, 9, 2004.

Yang, W., Yang, L., and Merchant, J.: An assessment of AVHRR/NDVI-ecoclimatological relations in Nebraska, USA, Int. J. Remote Sens., 18, 2161-2180, 1997.

Zhang, L., Dawes, W., and Walker, G.: Response of mean annual evapotranspiration to vegetation changes at catchment scale, Water Resour. Res., 37, 701-708, 2001.

Zhang, Z., Tian, F., Hu, H., and Yang, P.: A comparison of methods for determining field evapotranspiration: photosynthesis system, sap flow, and eddy covariance, Hydrol. Earth Syst. Sci., 18, 1053-1072, doi:10.5194/hess-18-1053-2014, 2014.
Zreda, M., Desilets, D., Ferré, T., and Scott, R. L.: Measuring soil moisture content non-invasively at intermediate spatial scale using cosmic-ray neutrons, Geophys. Res. Lett., 35, L21402, doi:10.1029/2008GL035655, 2008.

Zreda, M., Shuttleworth, W. J., Zeng, X., Zweck, C., Desilets, D., Franz, T., and Rosolem, R.: COSMOS: the COsmic-ray Soil Moisture Observing System, Hydrol. Earth Syst. Sci., 16, 40794099, doi:10.5194/hess-16-4079-2012, 2012. 